\title{
地震動を受ける貯蔵架台付きキャスクのロッキングモデル化手法の提案
}

\author{
近藤 俊介*1，白井 孝治*1，南波 宏介 ${ }^{* 2}$
}

\section{Proposal for the rocking analysis model of the dry cask for spent nuclear fuel attached to the storage pallet subjected to the strong earthquake motions}

\author{
Shunsuke KONDO ${ }^{* 1}$, Koji SHIRAI ${ }^{* 1}$ and Kosuke NAMBA ${ }^{* 2}$ \\ ${ }^{* 1, * 2}$ Central Research Institute of Electric Power Industry \\ 1646 Abiko, Abiko-shi, Chiba 270-1194, Japan
}

Received 31 August 2015

\begin{abstract}
In Japan, a dry cask for spent nuclear fuel attached to a storage pallet should be transferred and stored in the vertical orientation on the concrete floor in an interim spent nuclear fuel storage facility at or outside reactor site, and a transfer system using air supply will be adopted for such pallet. In case of the hypothetical event, the shutdown of the air supply due to the strong earthquake motions, it is important to evaluate a stability of the metal cask on the concrete floor during seismic motions. A dynamic analysis by the analysis code "TDAPIII" was executed with a simple lumped mass model by adopting joint elements between a concrete floor and pallet, to reproduce the rocking and sliding behavior. Joint stiffness values were equivalently set to the vibration modes obtained by an eigenvalue analysis. The seismic analysis results were compared with the previous shaking table test results with $2 / 5$ scale model of a real size cask. As a result, although discrepancies of the velocity response of the converted from maximum uplifting potential energy appeared in the range of $\mu \pm 3 \sigma(0.57 \sim 1.46)$ among 45 analysis cases comparing with experiment results, it was confirmed that maximum value was about 110kine considerably less than the overturning threshold value 190kine. Moreover, an applicability of the proposed prediction methodology to the real size model was also confirmed.
\end{abstract}

Key words : Metal cask, Storage pallet, Seismic response analysis, Spring-mass model, Spent fuel interim storage, Dry cask

\section{1. 緒言}

原子力発電所において発生する使用済燃料は，再処理工場に運搬して再処理を行い，ウランとプルトニウムを 回収し再利用することが可能な資源であり，エネルギ一資源を持たない我が国におけるエネルギーの長期的な安 定確保を可能にすることができる. 現在, 青森県六ヶ所村では, 再処理工場稼動に向けた準備が進められており, その処理能力は年間 800 トンと計画されている，我が国では，東京電力（株）福島第一原子力発電所の事故発生 前までは，それを超える年間 900 トン以上の使用済燃料が発生しており，今後，原子力発電所が再稼動した場合 にも，同程度の使用済燃料の発生量が見込まれる．そのため，原子力発電所から再処理工場に搬出されるまでの 間，使用済燃料を一時的に貯蔵する施設が必要となる，本論文では，原子力発電所の敷地内外を問わず，使用済 燃料を一時的に乾式貯蔵する施設を「乾式貯蔵施設」と称する。乾式貯蔵施設では, 使用済燃料は図 1 に示され る金属キャスク（以下，キャスク）と呼ばれる金属製の密封容器（直径約 $2.5 \mathrm{~m} \times$ 高さ約 $6 \mathrm{~m} \times$ 質量約 120 ton）の 内部に貯蔵される．乾式貯蔵施設内でのキャスク移送方式としてエア台車方式（川本，2005）を採用した場合， 地震時に空気の供給が停止された際に，貯蔵架台（以下，架台）付きキャスクの縦置き姿勢で床面に固縛されな

No.15-00479 [DOI:10.1299/transjsme.15-00479], J-STAGE Advance Publication date : 28 January, 2016

${ }^{* 1}$ 正員，（一財）電力中央研究所（下270-1194 千葉県我孫子市我孫子 1646）

*2 (一財) 電力中央研究所

E-mail of corresponding author: s-kondo@criepi.denken.or.jp 
い状態での様態が想定される，仮に，地震等によりキャスクが転倒して破損し，密封性能が損なわれた場合，放 射性物質を大気中に放散する恐れがあるため, キャスクの耐震安定性を評価しておくことが重要である.

地震時における剛体の転倒問題に関する既往の研究（秋山他，1996）では，ロッキングの開始条件は地震動の 入力加速度により与えられ, 転倒条件は入力速度により与えられることが示されている. 地震動の周期が短い場 合には相対的に入力加速度が大きくなり，ロッキングが生じやすくなるため，既往の研究で対象としていた地震 動には短周期のものが多く（秋山, 北村, 2006), 長周期地震動に対する知見は少ない. このため, 川口等 (川口 他，2012）は，ロッキング現象に関する相似則を考慮した架台付きキャスクの縮尺模型（以下，縮尺模型）を用 いた長周期地震動に対するコンクリート床版上での耐震試験を行い，縮尺模型のロッキング振動の挙動を明らか にした．さらに設計用入力エネルギーとして， ウインドウエネルギースペクトル $\left(V_{W E S}\right)$ を提案し, 簡便かつ保 守的に評価できることを提案している. 実設計においては, 形状の異なるキャスクや振動数特性の異なる地震動 に対する着床状態におけるキャスクの耐震安定性評価を効率的に実施する必要があり, 簡便な数值解析モデルの 開発が望まれている. 本報では，既報（川口他，2012）の耐震試験で得られたロッキング振動の挙動を動的応答 解析により示すことを目的とし，まず，既報（川口他，2012）の而震試験で用いた縮尺模型の概要と振動特性に ついて述べる. 次に, 着床状態における縮尺模型の地震時の安定性を評価するため, 汎用解析コード TDAPIIIの ジョイント要素を用いた解析モデルを提案して, 架台との剛性を考慮した動的応答解析を行い, 縮尺模型による 耐震試験との比較により予測精度を明らかにした，さらに，提案した解析モデルにより，相似則の対象とした実 機キャスクに対して動的応答解析の結果を示した.

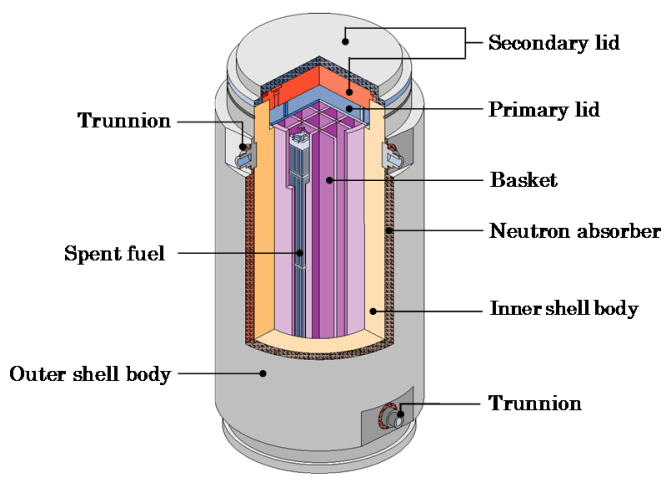

(Structural drawings of metal cask)

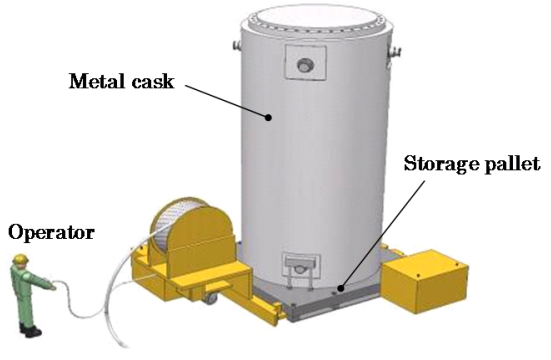

(Air Pallet)

Fig.1 Overview of dry cask for spent nuclear fuel attached to storage pallet. (In case the air supplied to an air pallet is stopped, it is assumed that metal cask is unfixed upright.)

\section{2. 相似則を適用した縮尺模型キャスク}

既報（川口他，2012）の耐震試験で対象とした実機および縮尺模型の仕様，ならびにコンクリート床版上にお ける縮尺模型の基本振動モードについて述べる.

\section{$2 \cdot 1$ 架台付きキャスクの主な諸元}

本論文で対象としたキャスクは，BWR使用済燃料用52体キャスクの公開情報（株式会社オー・シー・エル， 2007）を参照して設定した．表1に，対象とした実機キャスクと縮尺模型の諸元を示す．また，図2に縮尺模型の 貯蔵架台基本構造を示寸，相似則の換算率（縮尺模型／実機の比）については，ロッキング応答に影響を及ぼす 重心位置と上下方向の反発特性に着目をして, 以下の条件とした.

・実機から縮尺模型への縮尺は, 而震試験で使用する振動台の加振重量の制約から換算率 $2 / 5$ とした.

・実機と縮尺模型の転倒角度（架台全幅と重心高さの比）を相似とするために，カウンターウェイトを用いて 重心位置の調整を行った. 
・上下方向ばね剛性は, 架台の板厚に依存するため, 架台の板厚をパラメータとした架台付きキャスクモデル の固有值解析により, 上下方向振動数が相似となるように板厚を決定した.

・架台脚部に発生する脚部軸応力が実機と縮尺模型で一致するように, 脚部の等価断面積を決定した.

\section{$2 \cdot 2$ コンクリート床版上の縮尺模型キャスクの基本振動モード}

縮尺模型のコンクリート床版上の振動モードを把握するため，固有值解析を実施した．固有值解析に使用した 三次元解析コードは，有限要素解析コードLS-DYNA（PC版・倍精度実数版）である. 図3に固有值解析モデ ル，表 2 と表4に固有值解析に使用した金属材料およびコンクリート材料の物性值を示す．コンクリート材料の物 性值は，既報（川口他，2012）において示されている，実際の施設を想定したコンクリート材料を用いた強度試 験の值を適用した．解析モデルは，架台構造の非対称性を考慮し，等価高さ $(5985 \mathrm{~mm})$ と代表直径（2050 $\mathrm{mm}$ ）を有する三次元均質円柱体とした.

表3に，実機および縮尺模型キャスクの固有值解析の結果を示す．縮尺模型の上下方向基本振動数は $90.0 \mathrm{~Hz}$ なり，実機の上下方向基本振動数 $53.9 \mathrm{~Hz}$ の1.67倍となった. 適用した相似則についてみると，キャスク単体で設 定した振動数の換算率は $\sqrt{5 / 2}(=1.58)$ 倍であり, 縮尺模型単体に適用した換算率に比べると, コンクリート床 版の影響によりわずかに大きい值となっている.

Table 1 Specification of real size metal cask and scale model metal cask

\begin{tabular}{l|c|c|c}
\hline \multicolumn{1}{c|}{ Item } & Unit & Scale model & Real size \\
\hline Side length of storage pallet & $\mathrm{m}$ & 1.360 & 3.400 \\
\hline Height of center of gravity & $\mathrm{m}$ & 1.158 & 2.867 \\
\hline Mass & ton & 12.490 & 138.6 \\
\hline Inertia moment around the center of gravity & ton $\cdot \mathrm{m}^{2}$ & 6.848 & 588.9 \\
\hline Overturning angle & $\mathrm{rad}$ & 0.531 & 0.535 \\
\hline
\end{tabular}

Table 2 Physical property of a metal for eigenvalue analysis

\begin{tabular}{c|c|c|c|c}
\hline \hline \multirow{2}{*}{ Type } & Part & $\begin{array}{c}\text { Density } \\
\left(\text { ton } / \mathrm{mm}^{3}\right)\end{array}$ & $\begin{array}{c}\text { Modulus of } \\
\text { elasticity } \\
\left(\mathrm{N} / \mathrm{mm}^{2}\right)\end{array}$ & $\begin{array}{c}\text { Poisson's } \\
\text { ratio }\end{array}$ \\
\hline $\begin{array}{c}\text { Scale } \\
\text { model }\end{array}$ & $\begin{array}{c}\text { Counter weight } \\
\text { Upper }\end{array}$ & $7.88 \times 10^{-9}$ & $2.05 \times 10^{5}$ & 0.3 \\
& Lower & $7.87 \times 10^{-9}$ & $2.05 \times 10^{5}$ & 0.3 \\
\cline { 2 - 5 } & Cask body & & & \\
& Upper & $7.52 \times 10^{-9}$ & $2.05 \times 10^{5}$ & 0.3 \\
& Lower & $7.75 \times 10^{-9}$ & $2.05 \times 10^{5}$ & 0.3 \\
\cline { 2 - 5 } & Storage pallet & $7.85 \times 10^{-9}$ & $2.05 \times 10^{5}$ & 0.3 \\
\hline \multirow{2}{*}{ Real } & Cask body & $5.95 \times 10^{-9}$ & $2.05 \times 10^{5}$ & 0.3 \\
\cline { 2 - 5 } size & Storage pallet & $7.85 \times 10^{-9}$ & $2.05 \times 10^{5}$ & 0.3 \\
\hline
\end{tabular}

Table 3 Result of eigenvalue analysis

\begin{tabular}{c|c|c}
\hline \hline Type & $\begin{array}{c}\text { Scale } \\
\text { model }\end{array}$ & $\begin{array}{c}\text { Real } \\
\text { size }\end{array}$ \\
\hline X direction & $27.5 \mathrm{~Hz}$ & $15.3 \mathrm{~Hz}$ \\
\hline Y direction & $29.0 \mathrm{~Hz}$ & $16.2 \mathrm{~Hz}$ \\
\hline Z direction & $90.0 \mathrm{~Hz}$ & $53.9 \mathrm{~Hz}$ \\
\hline
\end{tabular}

Table 4 Physical property of a concrete slab for eigenvalue analysis

\begin{tabular}{c|c|c|c|c}
\hline \hline $\begin{array}{c}\text { Density } \\
\left(\text { ton } / \mathrm{mm}^{3}\right)\end{array}$ & $\begin{array}{c}\text { Shear modulus } \\
(\mathrm{MPa})\end{array}$ & $\begin{array}{c}\text { Bulk modulus } \\
(\mathrm{MPa})\end{array}$ & $\begin{array}{c}\text { Compressive strength } \\
(\mathrm{MPa})\end{array}$ & $\begin{array}{c}\text { Tensile strength } \\
(\mathrm{MPa})\end{array}$ \\
\hline $2.36 \times 10^{-9}$ & 14706 & 19607 & 38.4 & 3.2 \\
\hline
\end{tabular}




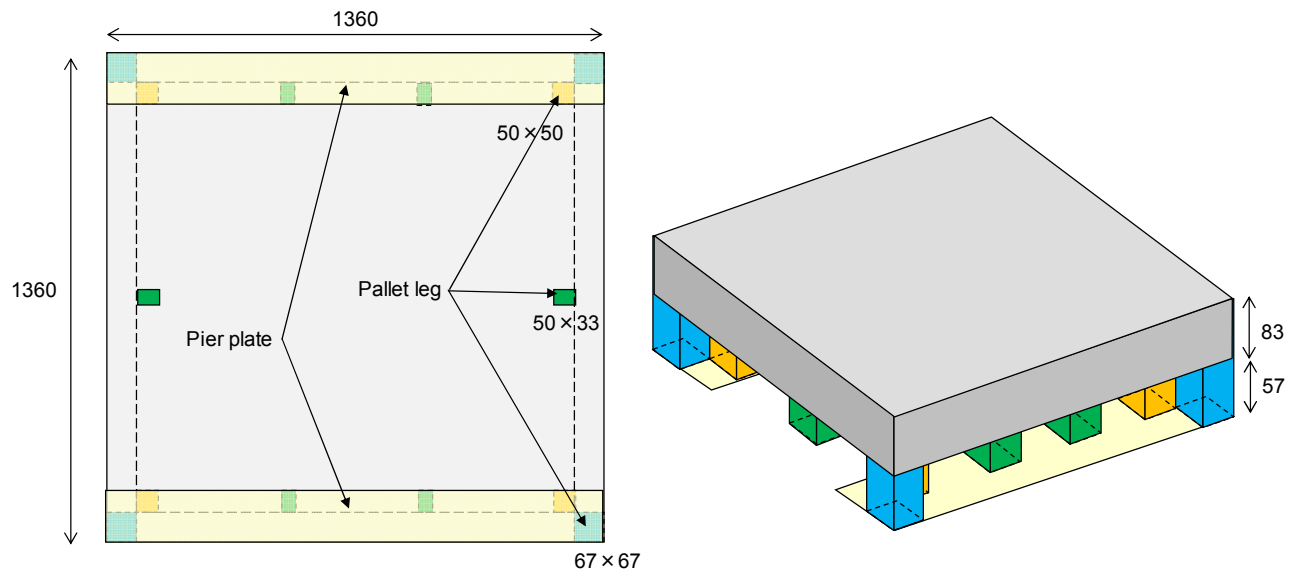

Fig.2 Structural drawings of storage pallet (scale model)

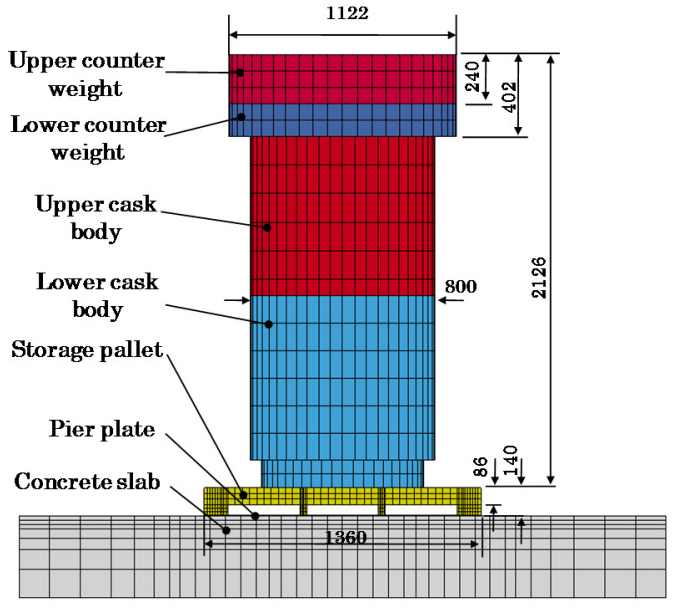

(Scale model metal cask)

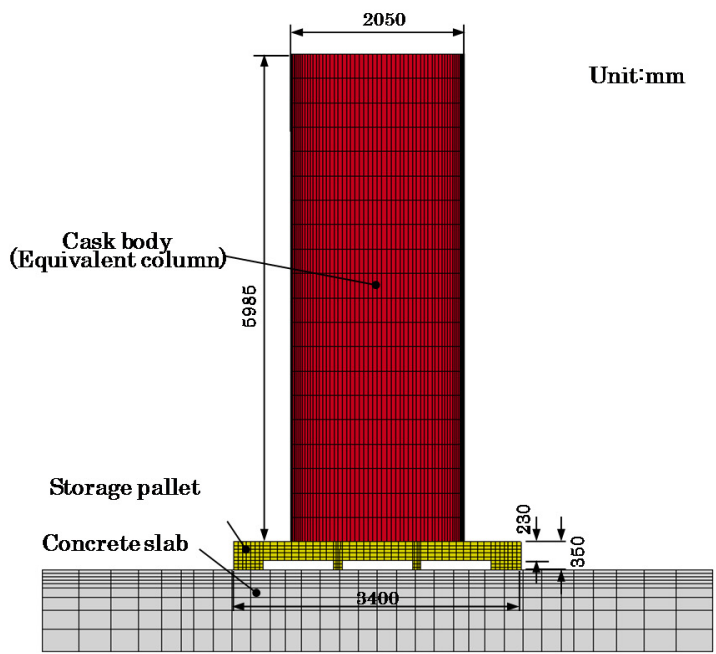

(Real size metal cask)

Fig.3 Eigenvalue analysis model of metal cask attached to storage pallet

\section{3. 縮尺模型を用いた動的解析手法}

キャスク単体における接触面の評価（白井他，1994，2003）は，半無限弾性体地盤上の復元力により決まるも のとされ，コンクリート強度により決定されるとある. 本報では，架台付きキャスクとコンクリート床版間の滑 りや浮上りを考慮したロッキング現象を再現するため, 汎用解析コード TDAPIII のジョイント要素を適用したバ ネ・質点系解析モデルを提案する. ジョイント要素は，一般的に地盤と構造物等の接触面をモデル化する際に用 いられており（土木学会，1989）, 1つのジョイント要素につき 4 つの節点からなり, 直方向とせん断方向にそ れぞれ 2 組のバネを有する（図 5 参照）。ロッキング挙動の再現性を考慮して，せん断方向の節点間隔は $1 \mathrm{~mm}$ とした。ジョイント要素剛性の設定については，ロッキング現象時の接触状態を考慮した固有值解析結果に基づ き設定するものとした。ささら，既報（川口他，2012）の耐震試験結果と比較を行い，解析モデルの妥当性評価 を実施した。

\section{$3 \cdot 1$ ロッキング現象時の接触状態を考慮した固有值解析}

ロッキング現象時の架台付きキャスクとコンクリート床版の接触状態は, 架台脚部の外側端部での線接触が想 定される，このため，固有值解析モデルとして，架台付きキャスクがコンクリート床版上に直立させた状態にお いて，コンクリート床版と接触する架台脚部の外側端部一列を拘束した際の振動モードを算出した。 なお，脚部 
プレートが介する部分は投影した脚部プレート面上を拘束するものとした．固有值解析は，2.2節と同様に，有 限要素解析コードLS-DYNAを使用した。 図4および表5に, 固有值解析における拘束条件と固有值解析結果を示 す. 図4の赤枠部が架台底面の拘束部を示寸. 本報では, ロッキング現象時の接触状況を考慮した固有值解析に より得られた振動数をロッキング振動数と呼称する. 水平方向および上下方向のロッキング振動モードについて は，水平方向ロッキング振動数は $24.1 \mathrm{~Hz}$ ，上下方向ロッキング振動数は $78.4 \mathrm{~Hz}$ であった.

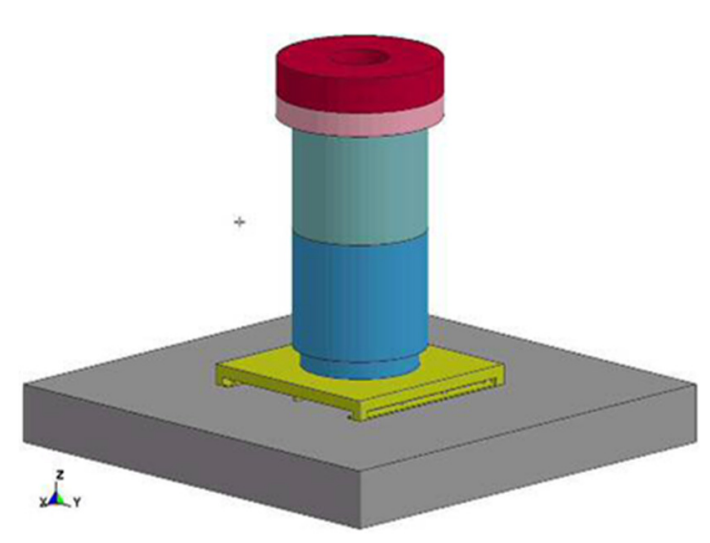

(Metal cask attached to storage pallet on concrete slab)

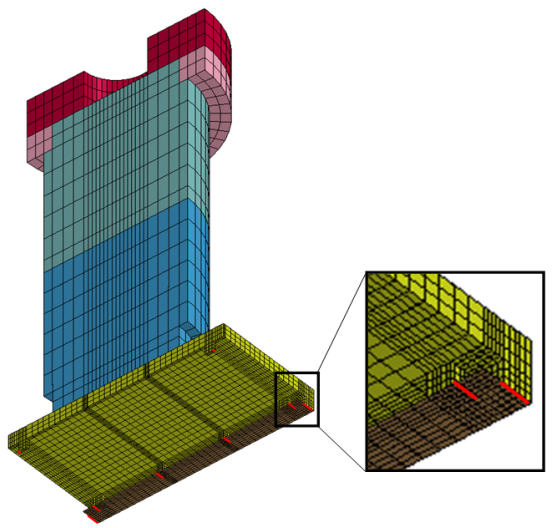

(Contact surface partial restriction for a joint stiffness setting)

Fig.4 Constraint condition of metal cask attached to storage pallet on concrete slab for eigenvalue analysis. A red part in figure shows restriction part.

Table 5 Eigenvalue analysis result of metal cask attached to storage pallet on concrete slab

\begin{tabular}{c|c|c}
\hline \hline Type & Horizontal direction & Vertical direction \\
\hline Fundamental frequency & $27.5 \mathrm{~Hz}$ & $90.0 \mathrm{~Hz}$ \\
\hline Rocking frequency & $24.1 \mathrm{~Hz}$ & $78.4 \mathrm{~Hz}$ \\
\hline
\end{tabular}

\section{$3 \cdot 2$ 解析モデル}

\section{$3 \cdot 2 \cdot 1 \quad 1$ 質点系解析モデル}

解析モデルは，縮尺模型本体と架台を一体化して，等価な質量と回転慣性を持つ 1 質点系モデルに置き換え， 微小な質量を有する質点と剛結させて形状を表現した. 架台とコンクリート床版間に設置するジョイント要素 は，架台の幅においてそれぞれ等間隔になるように配置した。

図5に，バネおよび質点を用いた 1 質点系解析モデルを示す．本解析モデルでは，滑りや浮上りにおける相対 変位を得るため，ジョイント要素として，1つの要素に直方向とせん断方向にそれぞれ 2 組のバネを用いた. シ ヨイント要素剛性については，前節で得られたロッキング振動数と等価となるように設定した．図6に，ジョイ ント要素剛性設定フローを示す．まず，直方向剛性について，ジョイントの個数に応じて上下方向振動数と等価 となるように決定した．次に，せん断方向剛性について，初期值を与えて水平方向振動数と等価になるまで繰り 返し計算を行い，決定した．コンクリート床版と架台間の摩擦係数は，正弦波の周波数をスイープした波形（振 幅 $3.0 \mathrm{~cm}$ 一定， $1.5-2.5 \mathrm{~Hz}(0.1 \mathrm{~Hz}$ 刻夕））を用いた振動試験で測定された值（静摩擦係数 0.63 , 動摩擦係数 0.63 ) とした. また, 減衰定数については上下方向基本振動数 $(90 \mathrm{~Hz})$ に対し, 剛性比例型の減衰 $0.5 \%$ を考慮した. 地震応答解析で評価する物理量は, 図7に示されるように, 架台付きキャスクを剛床上における質量 $M$ 均質 直方体の剛体としてモデル化した場合，モデルが回転することにより発生するロッキング角度 $\theta$ の時のエネルギ 
ーEを，速度に換算した応答エネルギー速度 $V$ で表すものとした，応答エネルギー速度 $V$ は式(1)で表される. $\Delta \mathrm{H}$ は重心位置の高さ変化量である.

$$
\begin{aligned}
& E=M g \Delta H=\frac{1}{2} M V^{2} \\
& V=\sqrt{2 g \Delta H}=\sqrt{2 g a\{\sin (\theta+\alpha)-\sin (\alpha)\}}
\end{aligned}
$$

\section{$3 \cdot 2 \cdot 2$ 復元モーメントの設定}

汎用解析コードTDAPIIIは，微小変形理論によるFEMプログラムであるため，モデルの回転によって自重によ り生じるモーメントは，モデルの質量を $M$, 重力加速度を $g$, 初期座標による腕の長さを $l_{0}$ とすると (図 5 参照), $M \times g \times l_{0}$ の一定值となる. このため, 一定值のモーメントと実際に回転によって生じる理論解のモーメントと の差をとり，架台端部を支点として負の復元モーメントを重心位置に設定した，図8に，回転角による復元モー メント設定值を示す．復元モーメントは，接触の有無に関わらず床面と架台の成す角度により設定されるため, 滑りや転倒が発生した場合にも適用される.

また, 設定した復元モーメントの妥当性を確認寸るため, 重心位置に転倒限界モーメント前後の水平 1 方向荷 重制御によるパラメータ解析を行い, 転倒過程の確認を行った. 図 9 に, 荷重制御による転倒過程を示す. 転倒 限界直前の荷重制御としたケース 1 では，転倒には至らず重心回転角は元の着床状態に戻っている，一方，荷重 をさらに加えたケース 2 では, 転倒に至っていることから, 復元モーメントが正しく設定されていることを確認 した.

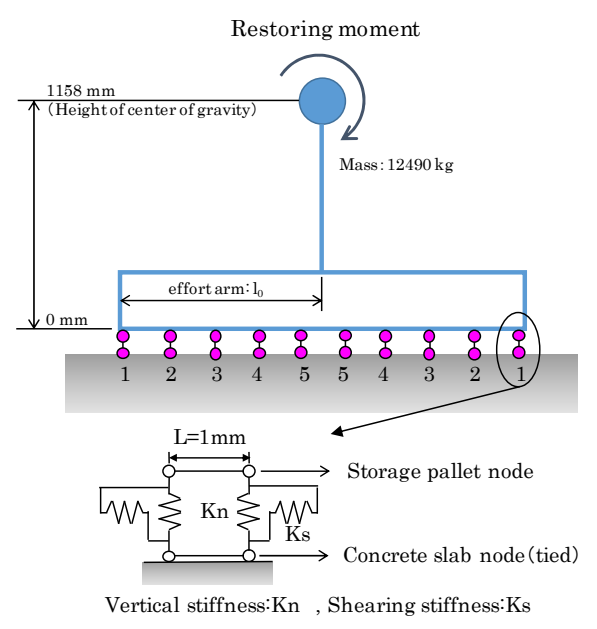

Fig.5 One mass point system analysis model

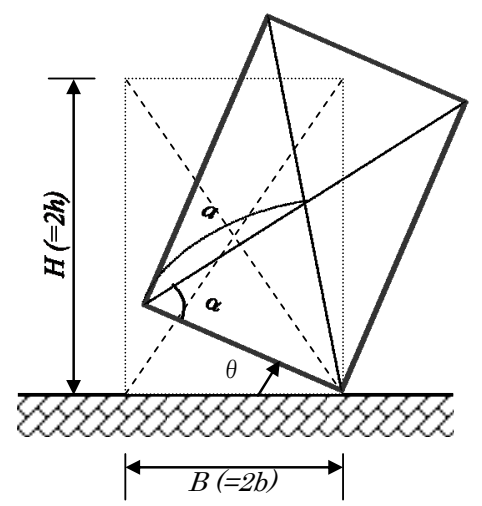

Fig.7 Two dimensional rocking model

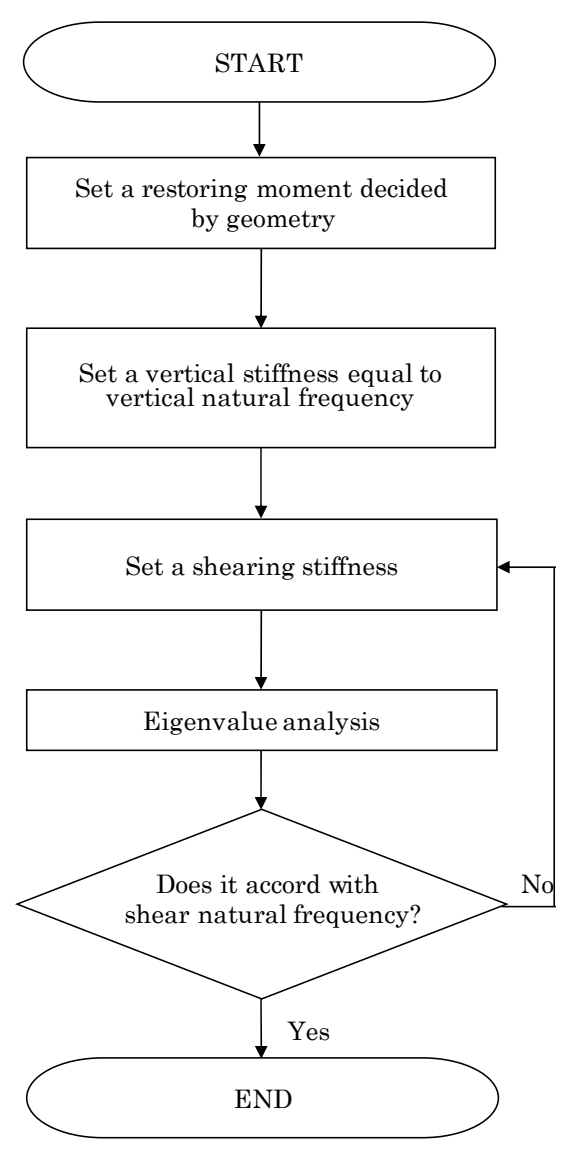

Fig.6 Joint element stiffness setting flow 


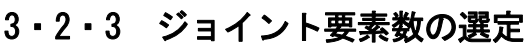

架台とコンクリート床版間のジョイント要素数をパラメータとした感度解析を実施した。表 5 に示すコンクリ 一下床版上の縮尺模型のロッキング振動数（水平方向 : $24.1 \mathrm{~Hz}$, 上下方向 : $78.4 \mathrm{~Hz}$ ) と等価となるように, 図 6 の設定フローに基づきジョイント要素剛性を決定した. ジョイント要素 14 個以上では，ロッキング振動数と 等価となる剛性值の設定が不可能であるため，ジョイント要素は 4，6，8，10，12 個とした.

図 10 に，ジョイント要素数に対する直方向剛性 $K n$ とせん断方向剛性 $K s$ の関係を示す. ジョイント要素数増 加とともに, 直方向剛性 $K n$ は減少し, せん断方向剛性 $K s$ は増加する傾向にある. ジョイント要素 10 本の時に $K n / K s=0.8$ となった.

次に，入力地震動波形（図 13 参照）として JMA 神戸（4 ケース），Taft（1 ケース），El Centro（1 ケース） を対象として，図 5 の解析モデルを用いて地震応答解析を実施した. 入力地震動波形は，耐震試験時にコンクリ 一ト床版上面の加速度計で観測された波形（水平 1 方向）を用いた．図 11 に，ジョイント要素数に対する地震 応答解析で得られた応答エネルギー速度の最大值と実験結果の最大值の比の関係を示す。なお，各プロットは全 6 ケースの入力地震動における平均值を示す. ジョイント要素数 10 個以上では安定した解析結果を得られてお

り，また，解析結果と実験結果の比は 1.0 以上となり，実験結果と比較して保守的な值が得られることが示され た. 以上の結果より，縮尺模型では，ジョイント要素数 10 個を適用した 1 質点系解析モデルを選定した.

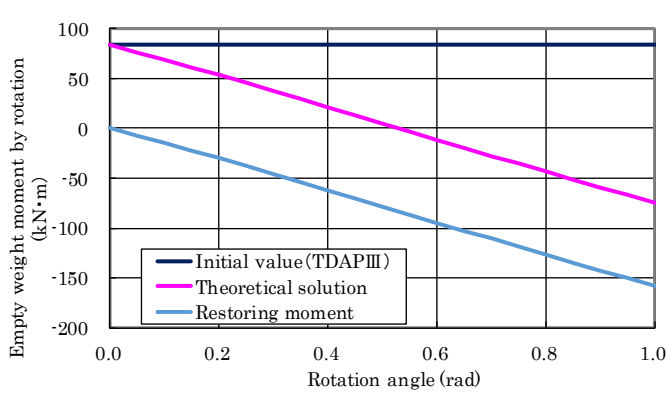

Fig.8 Restoring moment by rotation angle

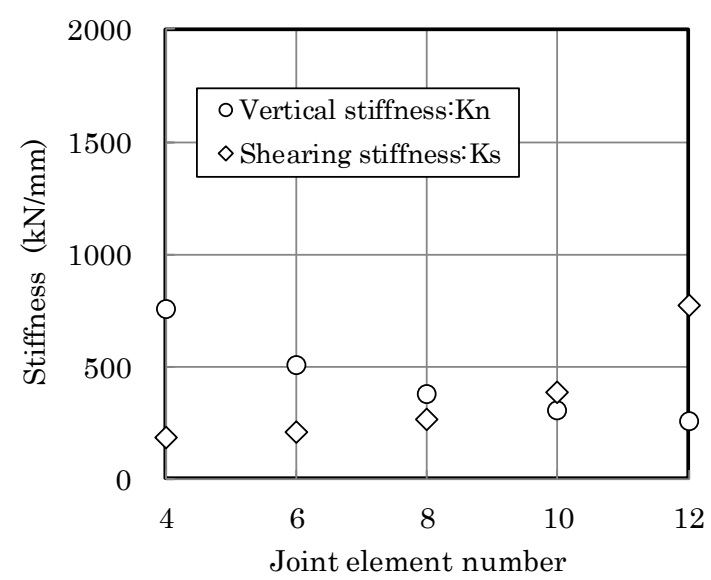

Fig.10 Stiffness by Joint element number

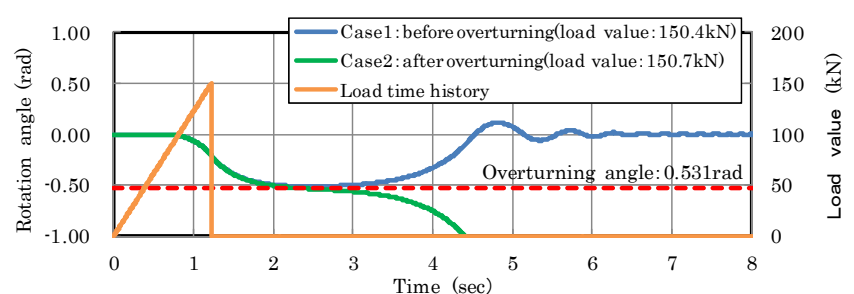

Fig.9 Overturning verification by load control

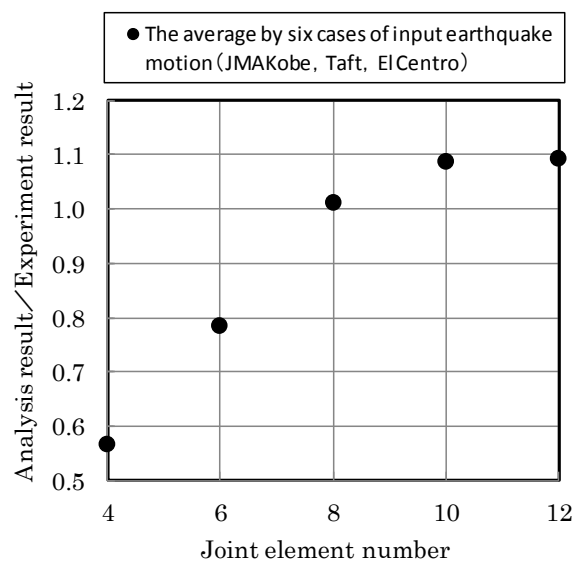

Fig.11 Earthquake response analysis by Joint element number

\section{$3 \cdot 2 \cdot 4$ 正弦波応答周期解による検証}

転倒問題を考える場合, 図 7 のように角柱剛体モデル（ $B$ : 縮尺模型の架台幅, $H / 2$ : 架台下端から重心ま での距離）として取り扱うことにより，モデルが正弦波加振を受ける際の周期解（小川，1980）を算出すること 
ができる．このため，前節で決定したバネ・質点系解析モデルを用いた正弦波加振解析を行い，これら正弦波応 答の周期解に対する検証を行った.

水平方向の地動加速度 $\ddot{u}$ 受け，剛床上で滑りを生じない場合のロッキング方程式は，式(2)で与えられる.

$$
\begin{aligned}
& \ddot{\theta}=n^{2} \ddot{u} \cos (\theta \pm(\pi / 2-\alpha))+n^{2} g \sin (\theta \pm(\pi / 2-\alpha)) \\
& n^{2}=\frac{M a}{I_{G}+M a^{2}}
\end{aligned}
$$

ここで, $\theta$ : ロッキング角度, $\ddot{\theta}:$ ロッキング角加速度, $g$ :重力加速度, $I_{G}$ : 重心回りの慣性モーメント, $M$ : 剛体質量, $a$ : 底面回転端から重心までの距離, $\pi / 2-\alpha$ : 静的転倒限界角度 である.

ロッキングによる転倒が問題となる場合には， $\theta \pm(\pi / 2-\alpha)$ は小さい值となるので，式(3)で近似される. なお，入は振動数の次元をもつ.

$$
\begin{aligned}
& \ddot{\theta}=n^{2} \ddot{u}+\lambda^{2} g \sin (\theta \pm(\pi / 2-\alpha)) \\
& \lambda^{2}=n \sqrt{g}
\end{aligned}
$$

角柱剛体モデルが，正弦波地震動 $\ddot{u}=A \sin \omega t （ A$ : 加速度振幅， $\omega$ : 角振動数）を受ける時の無次元応答角 度の周期解は，式(4)で与えられる.

$$
\begin{aligned}
& y=1-\frac{1}{\cosh (\pi / 2 \sigma)}-C \frac{P Q-\sqrt{P^{2}+1-Q^{2}}}{P^{2}+1} \\
& y=\frac{\theta}{\pi / 2-\alpha}, \sigma=\frac{\omega}{\lambda}, k=\frac{a}{g(\pi / 2-\alpha)}, C=\frac{k}{1+\sigma^{2}}, P=r \sigma d, Q=\frac{r d^{2}}{C}, d=\tanh \frac{\pi}{2 \sigma}, r=\frac{1-\delta}{1+\delta} \\
& \text { ここで, } y: \text { 無次元応答角, } \sigma: \text { 無次元振動数, } k: \text { 無次元加速度振幅, } \delta: \text { 角速度減衰率 である. }
\end{aligned}
$$

図 12 に，提案した 1 質点系解析モデルにおいて，一定変位振幅 $1.8 \mathrm{~cm}$ および $3.6 \mathrm{~cm}$ の正弦波を入力した際の 定常解として得られた加振振動数と無次元応答角の関係を示す．加振試験結果（川口他，2012）および周期解も あわせて示す。

解析結果は，実験值とよい対応を示しており，角速度減衰率 0.984 （減衰 $0.5 \%$ 相当）を適用した角柱剛体の 周期解とも良い対応を示していることから，前節で設定した解析モデルの設定方法の妥当性が示唆された.

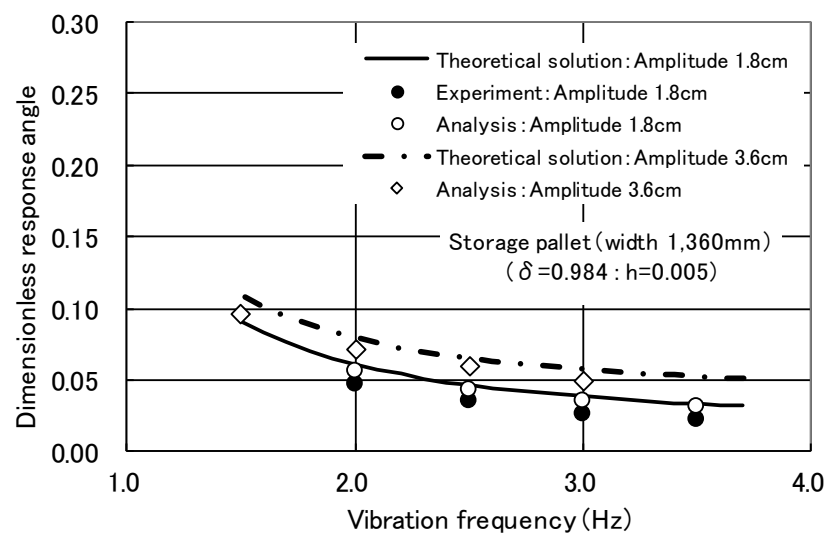

Fig.12 The relationship between vibration frequency and dimensionless response angle 


\section{$3 \cdot 3$ 地震応答解析}

前節で決定した 1 質点系解析モデルを用いて，入力地震動波形としてJMA神戸，Taft，El Centro，耐専波（評 価対象地における模擬地震動）を含む7種類の地震動波形を対象として，入力加速度をパラメータとした計45ケ ースに対して地震応答解析を実行した. 図13に, 本評価に用いた模擬地震動（総合資源エネルギー調査会,

2007）および観測記録地震動の加速度時刻歴を示す，縮尺模型の相似換算率に従い，加速度は1.0倍，継続時間 は0.632倍とした。

図14に, 汎用解析コードTDAPIII で得られた解析結果と実験結果の最大応答エネルギー速度の比較を示す．ま

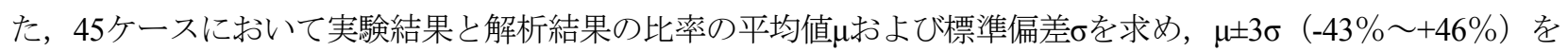
図中に記載した，実験結果と解析結果の比率のばらつきは $\mu \pm 3 \sigma の$ 範囲内にあることを確認され，汎用解析コー ドTDAPIIIによるバネ・質点系解析モデルがロッキング応答に対して有用な手法であることが示唆された.

図15に，設計用入力エネルギーとして提案したウインドウエネルギースペクトル（VWES（川口他，2012）と 解析による最大応答エネルギー速度の関係を示す. また，設計用地震動として想定している地震動波形において

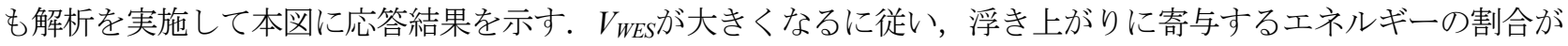
減少し, 最大応答エネルギー速度の值が頭打ちとなる傾向にあり, $V_{W \mathrm{ES}}$ が約 100 kineを超える入力の範囲では, 解析結果における応答值は図中の45度ラインの下側となっている．この傾向は既報（川口他，2012）の実験結果 と同様の傾向を示すことを確認できた．また，解析における応答エネルギー速度の最大值も約110kineであり， 転倒限界190kineの60\%程度で収まることが明らかになった。

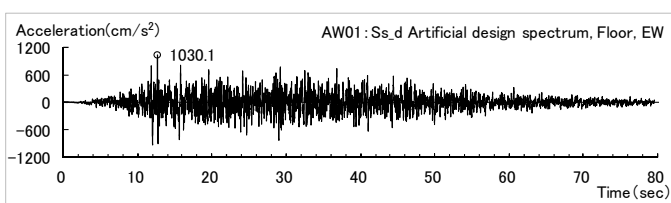

(AW01: Ss_d Artificial design spectrum, Floor, EW)

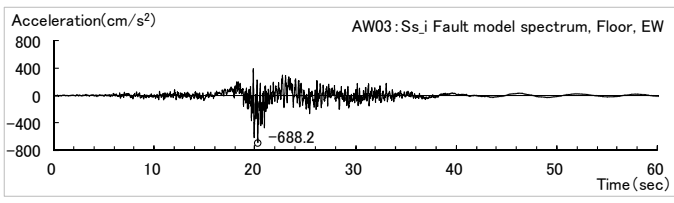

(AW03 : Ss_i Fault model spectrum, Floor, EW)

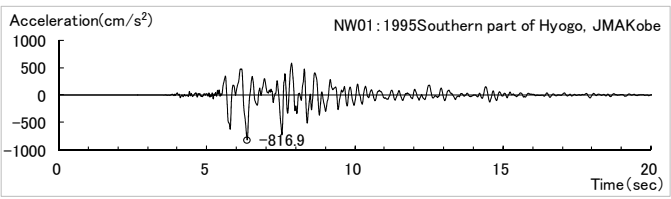

(NW01 : 1995 Southern part of Hyogo, JMA Kobe)

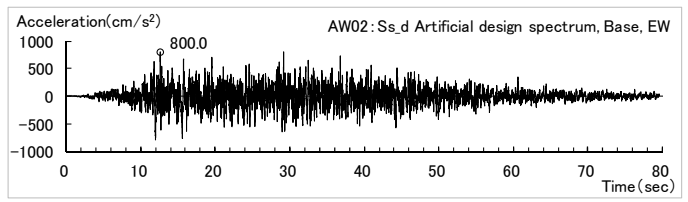

(AW02 : Ss_d Artificial design spectrum, Base, EW)

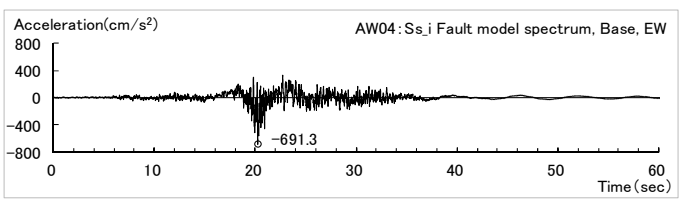

(AW04 : Ss_i Fault model spectrum, Base, EW)

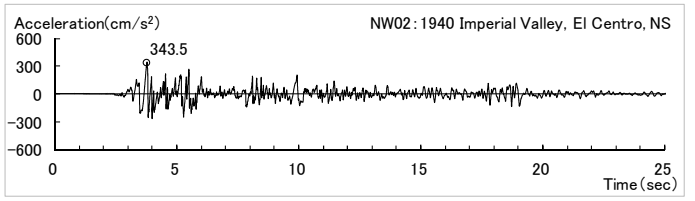

(NW02 : 1940 Imperial Valley, El Centro, NS)

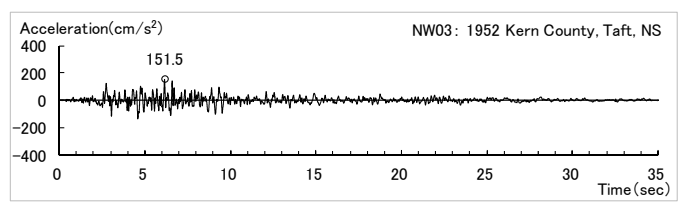

(NW03 : 1952 Kern County, Taft, NS)

Fig.13 Acceleration time history of simulated earthquake motions and observed earthquake motions 


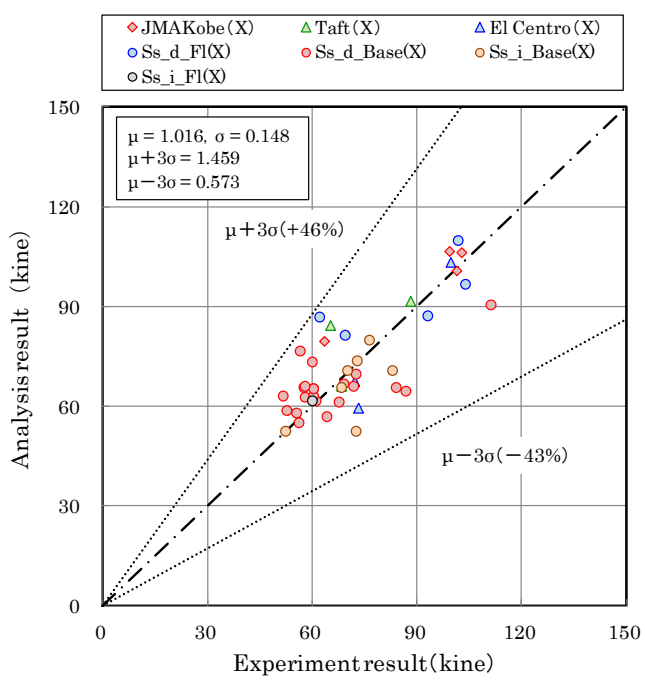

Fig.14 The relationship between analysis result by TDAPIII and experiment result. (These plots show the biggest response energy velocity.)

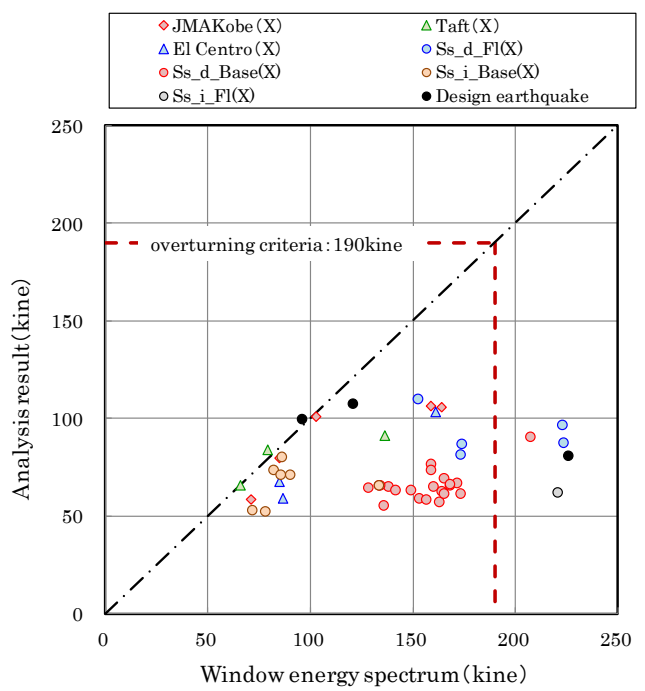

Fig.15 The relationship between window energy spectrum and analysis result.

\section{4. 実機サイズモデルの地震応答予測への適用性}

本章では，3章で述べた応答評価手法に基づき，図 3 に示す実機サイズモデルを用いたロッキング応答解析を 実施し，実機サイズモデルへの適用性を確認した.

\section{$4 \cdot 1$ 実機サイズモデルにおける固有值解析}

縮尺模型と同様に，コンクリート床版上の架台付きキャスクを対象として，有限要素法（LS-DYNA）による 固有值解析を行い，ロッキング現象時の架台付きキャスクとコンクリート床版の接触状態を考慮した拘束条件に おける, 水平方向および上下方向のロッキング振動数を求めた. 表6に, 実機サイズモデルにおける固有值解析 結果を示す．ロッキング振動数は，水平方向 $12.3 \mathrm{~Hz}$ ，上下方向 $41.9 \mathrm{~Hz}$ あ゙る.

\section{$4 \cdot 2$ 実機サイズモデルにおける 1 質点系解析モデル}

縮尺模型と同様に，本体と架台を一体化して等価な質量と回転慣性を持つ 1 質点系モデルに置き換え，微小な 質量を有する質点と剛結させて形状を表現した．架台とコンクリート床版間に設置するジョイント要素は，それ ぞれ等間隔になるように配置した．図16に，実機サイズモデルにおける 1 質点系解析モデルを示寸．コンクリー 卜床版と架台間の摩擦係数は, 静摩擦係数 0.63 , 動摩擦係数 0.63 とした. 減衰定数については, 上下方向基本振 動数 $53.9 \mathrm{~Hz}$ に対し，剛性比例型の減衰 $0.5 \%$ を考慮した. 図17に，回転角による復元モーメント設定值を示寸. 復元モーメントは，実機サイズキャスクの幾何学形状と質量により決定した.

図 6 の設定フローに基づき, 架台とコンクリート床版間のジョイント要素数をパラメータとした感度解析を実 施し，表 6 に示寸コンクリート床版上の実機サイズのロッキング振動数（水平方向 : $12.3 \mathrm{~Hz}$ ，上下方向 : 41.9 $\mathrm{Hz})$ と等価となるようにジョイント要素剛性を求めた. 図 18 に，ジョイント要素数における直方向剛性 $K n$ と せん断方向剛性 $K s$ の関係を示す. ジョイント要素 12 本の時に $K n / K s=1.0$ となった.

次に，入力地震動波形として，図 13 のうち JMA 神戸（4 ケース）, Taft（1 ケース）, El Centro（1 ケース） を対象として, 地震応答解析を実施した. 図 19 に, ジョイント要素数における地震応答解析で得られた応答工 ネルギー速度の最大值と実験結果の最大值の比の関係を示寸．なお，各プロットは全 6 ケースの入力地震動にお ける平均值を示す. ジョイント要素数 12 個以上で安定した解析結果を得られており，また，解析結果と実験結 
果の比は 1.0 以上となり, 実験結果と比較して保守的な值が得られることが示された. 以上の結果より, 実機サ イズモデルでは，ジョイント要素数 12 個を適用した 1 質点系解析モデルを選定した.

\section{$4 \cdot 3$ 実機サイズモデルにおける地震応答解析}

実機サイズモデルを用いた地震応答解析では，入力地震動波形としてJMA神戸，Taft，El Centro，耐専波（評 価対象地における模擬地震動）を含む5種類の地震動波形を対象として，入力加速度をパラメータとした計19ケ ースに対して解析を実行した。図20に，汎用解析コードTDAPIIIで得られた解析結果と実験結果の最大応答エネ ルギー速度の比較を示す．なお，実機サイズモデルの解析結果は実験結果と比較するために，速度の換算率 $\sqrt{2 / 5}$ (=0.632) を乗じた. 縮尺模型モデルでは, 解析結果と実験結果が均等にばらついているのに対して, 実 機サイズモデルでは，解析結果が実験結果をわずかに上回る傾向が見られた。これは，コンクリート床版強度を 相似則に関わらず同一としているため，表3で示した固有値解析結果に示すとおり，縮尺模型の上下方向基本振 動数が, 相似則換算率よりも若干大きい值となっており, 縮尺模型モデルよりも実機サイズモデルの応答が大き くなったものと考えられる.

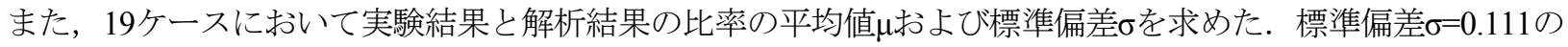
時， $\mu \pm 3 \sigma$ 值は- $25 \%$ +42\%であり，実機においてロッキング転倒評価をする場合には，ばらつきを考慮した 裕度を含む設計をする必要があることが示唆された.

さらに，想定されている設計用地震動（3種類）を用いた地震応答解析を実施した．図21に応答エネルギー速 度の時刻歴を示す. どのケースにおいても最大応答エネルギー速度は100 kine以下であり, 転倒限界190kineと比 較して十分に余裕のある結果が示された。

Table 6 Eigenvalue analysis result of metal cask attached to storage pallet on concrete slab (real size model)

\begin{tabular}{c|c|c}
\hline \hline Type & Horizontal direction & Vertical direction \\
\hline Fundamental frequency & $15.3 \mathrm{~Hz}$ & $53.9 \mathrm{~Hz}$ \\
\hline Rocking frequency & $12.3 \mathrm{~Hz}$ & $41.9 \mathrm{~Hz}$ \\
\hline
\end{tabular}

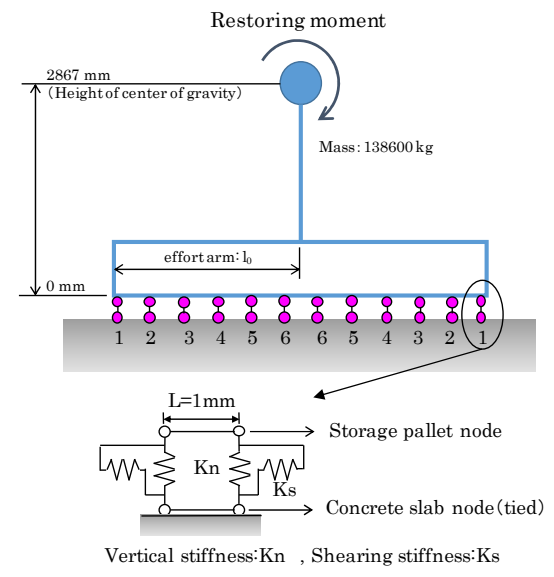

Fig.16 One mass point system analysis model (real size model)

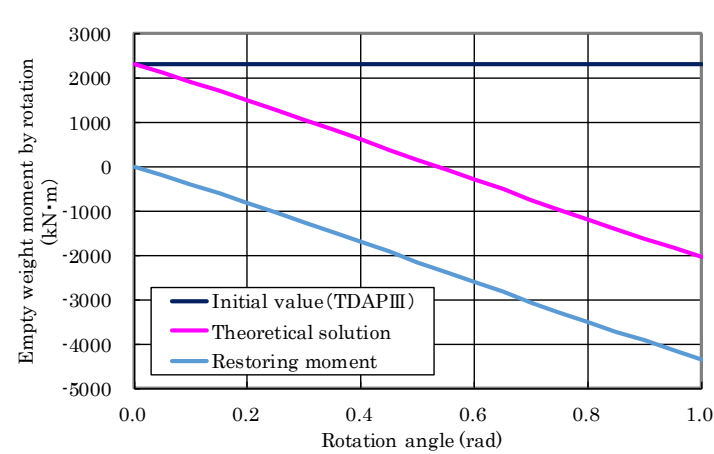

Fig.17 Restoring moment by rotation angle (real size model) 
Kondo, Shirai and Namba, Transactions of the JSME (in Japanese), Vol.82, No.834 (2016)

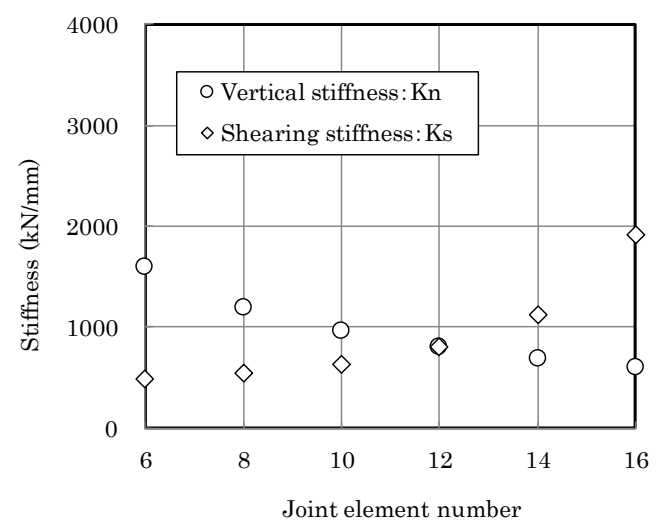

Fig.18 Stiffness by Joint element number (real size model)

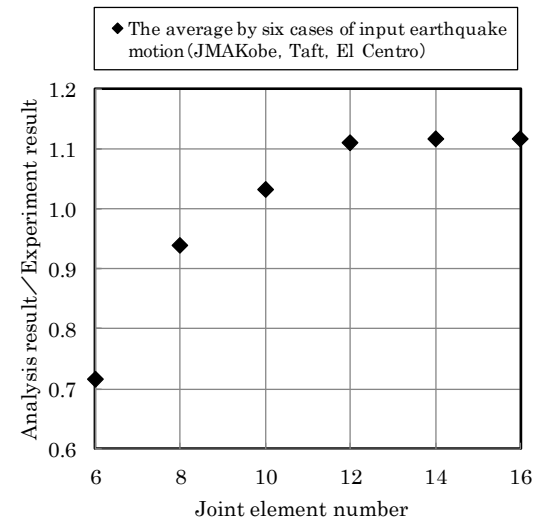

Fig.19 Earthquake response analysis by Joint element number (real size model)

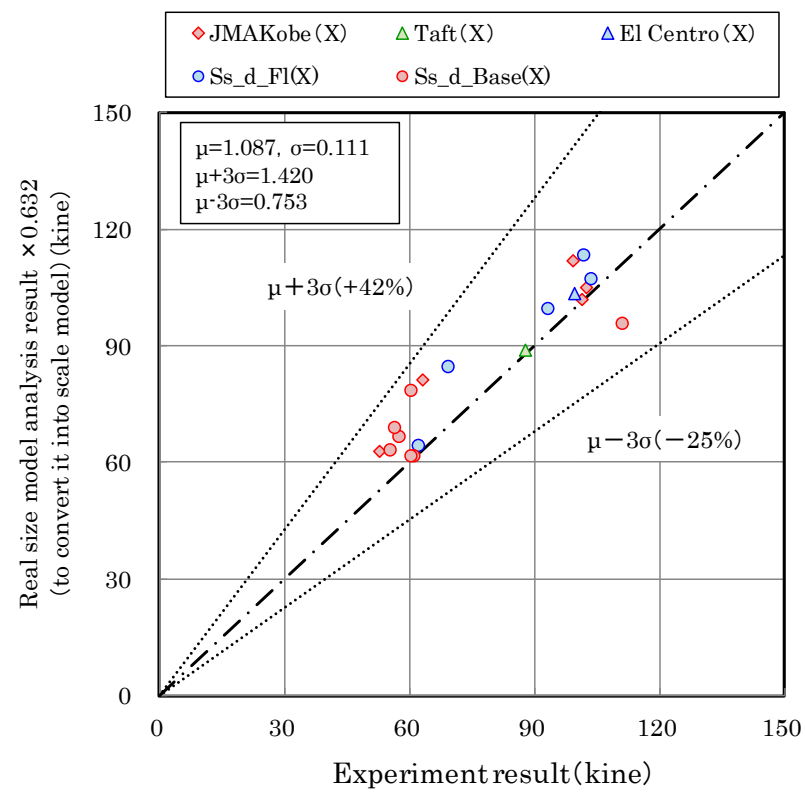

Fig.20 The relationship between analysis result of real size model by TDAPIII and experiment result. (These plots show the biggest response energy velocity. Analysis result of real size model needs to convert it into scale model because seismic experiment used scale model.)

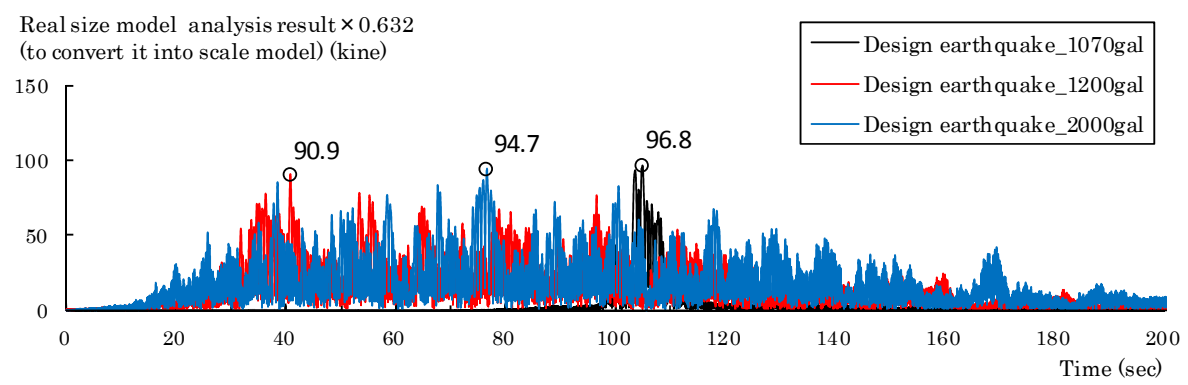

Fig.21 Analysis result time history of real size model used design earthquake 


\section{5. 結言}

滑りや浮上りを考慮したロッキング応答評価に対して, バネ・質点を適用したモデル（汎用解析コードTDAP III）の適用性を検討するため, 而震試験結果との比較を行いつつ, バネ・質点系モデルの動的解析手法を提案 し, 以下の結論を得た.

（1）コンクリート床版上に拘束した架台付きキャスクの固有值解析を実施し, 得られたロッキング振動数と 等価となるように，架台とコンクリート床版間にジョイント要素を設定した．このジョイント要素とキ ヤスク本体と架台を一体化した 1 質点系解析モデルを提案し, 解析結果と耐震試験結果との最大応答工 ネルギー速度の比較・検証を行った．その結果，45 ケースの入力地震動波形において，解析結果のば らつきは $\mu \pm 3 \sigma （-43 \%$ +46\%) の範囲内にあることを確認した.

（2） ウインドウエネルギースペクトル（ $\left.\mathrm{V}_{\mathrm{WES}}\right)$ と解析で得られた最大応答エネルギー速度の関係を求めた. $\mathrm{V}_{\mathrm{WES}}$ が 100kine を超える範囲では一定值へ収束するという実験結果と同様の傾向が確認され，その際の 最大エネルギー応答速度は約 110kine であり，転倒限界速度 190kine の 60\%程度で収まることを明らか にした.

（3） 相似則の対象とした実機キャスクモデルにおいて，提案モデルを用いて地震応答解析を実施したそその 結果，実機モデルの解析結果のばらつきは，標準偏差 $\sigma=0.111 の$ 時， $\mu \pm 3 \sigma の$ 值は-25\%〜+42\%であり， 実機においてロッキング転倒評価をする場合には，ばらつきを考慮した裕度を含む設計をする必要があ ることが示唆された.

（4）長周期成分を含む設計用地震動を用いた実機サイズモデルでの地震応答解析において，最大応答エネ ルギー速度は100 kine以下であり, 転倒限界190kineと比較して十分に余裕のある結果が示された.

\section{文献}

総合資源エネルギー調查会原子力安全・保安部会耐震・構造設計小委員会地震・津波，地質・地盤合同ワーキン ググループ, 浜岡原子力発電所 3,4 号機「発電用原子炉施設に関する耐震設計審查指針」の改訂に伴う而震 安全評価に関わる報告のうち基準地震動 Ss の策定 敷地ごとに震源を特定して策定する地震動の検討のうち プレート間地震の地震動評価（補足説明） 最近の知見を考慮した場合のプレート間地震の地震動評価への影 響について (2007),合同W3-3.

秋山宏, 伊山潤, 原田幸博, エネルギースペクトルを用いた剛体の転倒予測, 日本建築学会構造系論文集, No.488(1996), pp.49-55.

秋山宏, 北村春幸, エネルギースペクトルと速度応答スペクトルの対応, 日本建築学会構造系論文集, No.608(2006), pp.37-43.

土木学会, 動的解析の方法, 技報堂出版(1989), pp.123-125.

川口昇平, 白井孝治, 金澤健司, 搬送中の貯蔵架台付き金属キャスクの長周期地震動に対する地震時安定性評

価，土木学会論文集 A1（構造・地震工学），Vol.68， No.2(2012), pp.271-286.

川本敦史，使用済燃料中間貯蔵施設の計画と技術開発，平成 17 年度火力原子力発電大会(2005).

株式会社オー・シー・エル，使用済燃料中間貯蔵施設における金属製乾式キャスクについて（NEO-2552CB 型),

OCL-TR-002(2007).

小川信行，剛体の転倒振動に関寸る研究，日本建築学会論文報告集，No.287(1980), pp.51-63.

白井孝治, 平田和太, 三枝利有，コンクリートキャスクの確証試験(10)一耐震性評価一, E48，2003年日本原子

力学会秋の大会(2003). 
白井孝治, 龍博志, 伊藤千浩, 三枝利有, 地震荷重を受ける使用済燃料貯蔵容器の転倒安定性, 日本原子力学会 誌, Vol.36, No.11(1994), pp.1068-1078.

\section{References}

Advisory Committee for Natural Resources and Energy, Nuclear and Industrial Safety Subcommittee, Seismic and Structural Design Subcommittee, Joint Working Group of Earthquake, Tsunami and Geology, Ground, The establishment of design basis earthquake ground motion(Ss) among the report relating to seismic safety evaluation with revision of regulatory guide for reviewing seismic design of nuclear power reactor facilities about unit 3,4 of Hamaoka nuclear power plant. Ground motion evaluation of inter-plate earthquake among the study of ground motion to establish and to identify the epicenter for each site. (Supplementary explanation), about the impact to the ground motion evaluation of inter-plate earthquake in the case of considering the recent findings(2007), W3-3 (in Japanese).

Akiyama, H., Iyama, J. and Harada, Y., Estimate of overturning of rigid bodies with energy spectrum, Journal of Structural and Construction Engineering, No.488 (1996), pp.49-55 (in Japanese).

Akiyama, H. and Kitamura, H., Relationship between energy spectra and velocity response spectra， Journal of Structural and Construction Engineering, No.608 (2006), pp.37-43 (in Japanese).

Japan Society of Civil Engineers, Method of dynamic analysis (1989), pp.123-125, Gihodo Shuppan (in Japanese).

Kawaguchi, S., Shirai, K. and Kanazawa, K., Stability evaluation of metal cask attached to a transfer pallet during longperiod seismic motions, Journal of Japan Society of Civil Engineers, Ser. A1 (Structural Engineering \& Earthquake Engineering), Vol.68, No.2(2012), pp.271-286 (in Japanese).

Kawamoto, A., Engineering development of spent fuel storage facility, Thermal and Nuclear Power Generation Convention (2005) (in Japanese).

OCL corporation, About metal dry cask in interim storage facility for spent fuel (type NEO-2552CB), OCL-TR-002(2007) (in Japanese).

Ogawa, N., Study on the overturning vibration of rigid structure, Transactions of the Architectural Institute of Japan, No.287 (1980), pp.51-63 (in Japanese).

Shirai, K., Hirata, K. and Saegusa, T., Verification tests on concrete casks (10) -seismic evaluation-, Session ID: E48, 2003 Fall Meeting of Atomic Energy Society of Japan (2003) (in Japanese).

Shirai, K., Ryu, H., Ito, C. and Saegusa, T., Tip-over stability of spent fuel storage cask subjected to seismic load, Journal of the Atomic Energy Society of Japan， Vol.36， No.11(1994)， pp.1068-1078 (in Japanese). 